\section{Sanctuary in Nigeria for possible fourth subspecies of gorilla}

A conservation programme is under way in the Afi Mountains of Nigeria's Cross River State, with the aim of establishing a wildlife sanctuary to protect the most westerly population of gorillas in the world, along with other rare and endangered species, such as the drill and chimpanzee. Recent research suggests that these gorillas belong to a neglected fourth subspecies of this great ape, which is usually considered to be divided into three subspecies.

The Afi Mountains are located in the north-western corner of the Afi River Forest Reserve, whose ecological integrity is severely threatened by hunting, farm encroachment, fire and logging. Because access is quite difficult and logging pressures are minimal in the mountainous north-west portion of the reserve, a relatively full complement of its component fauna and flora has survived until today. For this reason, 8000 ha of the forest reserve, including the mountains and some adjacent areas, was proposed in 1990 as a wildlife sanctuary.

Relatively small-scale conservation actions have been under way for the proposed sanctuary since that time. A local non-governmental organization (NGO), Pandrillus, pursuing captive breeding and rescue of orphaned drills and chimpanzees, based its field camp in community forest adjacent to the proposed sanctuary in the mid-1990s. In addition to these programmes, Pandrillus has run public awareness and community consultation campaigns about conservation and proper management of the reserve. They have organized antihunting patrols, and contributed to on-going boundary clearance and maintenance activities.

Primatologist John Oates, who led the team that originally recommended the designation of a wildlife sanctuary, has continued to be involved in research in the Afi Mountains through his doctoral student Kelley McFarland, from the City University of New York. This research, supported by the Wildlife Conservation Society (WCS), the Leakey Foundation and others, has gathered the first detailed evidence on the ecology of gorillas in the Nigeria-Cameroon border region. McFarland has also collected hairs from the night sleeping nests of the Afi gorillas, and DNA from these hairs is being extracted for analysis. Early results from a small sample indicate large genetic differences between this population and other western gorillas.

Such findings add to the results of measurements on the skulls of gorillas from the Nigeria-Cameroon border region, which support recognition of these animals as belonging to a distinct subspecies, Gorilla gorilla diehli (based on a name originally given to gorilla specimens from this area in 1904 by the German scientist Paul Matschie, who regarded them as a separate species). Gorilla g. diehli may be conveniently referred to in English as the Cross River gorilla.

Fewer than 200 Cross River gorillas still survive, making it the rarest of the gorilla subspecies. They are separated into five isolated subpopulations on both sides of the Nigeria-Cameroon border, with little hope of them ever interbreeding again without intervention.

In late 1998, Oates and McFarland conceived a structured programme for patrols and research at the proposed wildlife sanctuary, building on the work of Pandrillus over the years and on the activities of McFarland's research team. This programme began in mid-1999 under the supervision of a Liberian volunteer, James Coleman, with support from the Bernhardine Fund, WCS, Primate Conservation Incorporated, the Netherlands Committee for IUCN, Pandrillus and Fauna \& Flora International. Fieldwork is complemented by a series of community consultations led by the Cross River State Forestry Development Department on the establishment of the sanctuary, and by demarcation of the boundary. This 'bridging phase' of conservation at Afi is intended to last until such time as the wildlife sanctuary is legally gazetted and long-term funding is provided for establishing a comprehensive management programme.

Jamison Suter, Fauna \& Flora International, Cambridge, UK

Dr John Oates, Hunter College, New York, USA

\section{Liberia's forests on the block?}

Liberia is home to two of the three remaining large blocks of contiguous forest in the Upper Guinean Forest Ecosystem, an area of extraordinary biological richness, which once stretched from southern Togo and Ghana across to Sierra Leone and Guinea. Liberia contains an estimated 43 per cent of the remaining Upper Guinean rain forest, making it the key country for the survival of this ecosystem. Outside of Liberia and Tai National Park (Côte d'Ivoire), this forest survives essentially in fragments, which face intense pressures and are rapidly disappearing or being degraded.

In the 1970s and 1980s, the Liberian Forestry Development Authority (FDA) began planning and creating a protected-area system with the assistance of WWF, IUCN and the US Peace Corps. Sapo National Park, Liberia's 
first and only national park, was created in 1983 and covers $1308 \mathrm{sq} \mathrm{km}$ of relatively undisturbed forest in the south-east of the country. Plans were laid to create another two national parks - Lofa-Mano National Park in the north-west, and Cestos-Senkwehn National Park in the south-centre, incorporating much of the KrahnBassa National Forest-and five nature reserves scattered across the country.

The civil war of 1989-96 left the country's economy, infrastructure and institutions in shambles. In 1997, a former rebel faction leader, Charles G. Taylor, was elected president but his government has had difficulty in gaining international confidence. Since the return of peace, no new international donor has initiated a sizeable programme to assist Liberia's reconstruction and those that maintained a presence during the war-the European Commission, the USA and the United Nations-have continued channelling nearly all their support through NGOs or managing it directly.

Very little support has been mobilized to restart forest management and conservation activities. Most donors have felt uneasy supporting work in a potentially unstable country, and those that work there generally feel that humanitarian and basic development assistance are the first priority. The FDA has been starved of its basic operating budget, which has been eroded by inflation since before the war to less than 5 per cent in real terms of what it was in the 1980s. By the end of September 1999, despite widespread logging across the country, the FDA had received from the National Treasury only 17 per cent of its annual budget, implying that its 1999 real operating budget has been perhaps 1 per cent of what it was in the pre-war period.

Since 1992, the European- and US-based Society for the Renewal of Nature Conservation in Liberia (SRNCL) has fought to raise awareness and mobilize funds for supporting conservation in Liberia, particularly by supporting the staff of the Wildlife and National Parks Division of the FDA and the Society for the Conservation of Nature of Liberia (SCNL), the country's premier conservation NGO. Together, SRNCL, FDA and SCNL undertook numerous surveys, small-scale conservation actions in and around Sapo National Park, and public awareness efforts.

Most of SRNCL's and SCNL's efforts have concentrated in the south-east of the country, in the proposed Cestos-Senkwehn National Park and around Sapo National Park. In March of 1997 and 1998, members of SRNCL and SCNL travelled the logging road between Buchanan and Greenville, which had been constructed largely during the war and passes through the heart of the proposed Cestos-Senkwehn National Park, and noticed the rapid advance of settlement and other incursions. This prompted them, with Fauna \& Flora
International's (FFI) assistance, to mount a 2-month survey of the area in January and February 1999, involving aerial overflight, road and river reconnaissance, interviews with local hunters and forestry workers, and rapid faunal assessments. The 1999 survey team recorded an explosion of settlement, shifting agriculture and commercial hunting in formerly inaccessible and some legally protected areas, and significant declines in wildlife compared with previous years, following the advance of forestry activities. Little evidence of the FDA's presence was seen.

Following the survey, a workshop in March 1999, with the FDA's active participation, devised a series of recommendations for restarting conservation programmes in Liberia, as part of a broader programme to revitalize forest management and the FDA. In collaboration with the FDA, NGO partners and bilateral and multilateral donors prepared and submitted several proposals following up on the recommendations. These would assess the status of forest cover nationally, assess wildlife populations in the south-east forest block, restart active management at Sapo National Park and build capacity in the FDA to plan and manage a protected-area system.

However, efforts to restart active management of Liberia's forests are currently in grave danger. To attract major foreign capitalization of logging operations, the top levels in government recently decided to reduce the number of forest concessions from 15-20 to 4-5. A deal was agreed in August-September between a Malaysian group and Liberian-based investors (of Dutch, Lebanese and Liberian nationality) to form the LiberianMalaysian Timber Company (LMTC), which will operate out of Buchanan, at the western edge of the south-east Liberian forest block. They are reported to boast the motto 'waste no tree'. This company has already brought in 250-300 Malaysians to operate the factory and manage cutting operations and exports. They are expected to invest upwards of \$US 50 million in Liberia and have obtained a concession of $16,000 \mathrm{sq} \mathrm{km}$, all of it in the south-east forest block, much of it apparently in the proposed national park and adjacent to Sapo National Park.

Recent reports, which are difficult to verify and somewhat conflicting, indicate that a Malaysian venture, named Oriental Timber Company (OTC), which may be another name for LMTC, is investing \$US 50 million, perhaps the same \$US 50 million as above or perhaps it is additional. The OTC will upgrade the BuchananGreenville road to a four-lane all-year highway, and reinforce the bridges. Today it is narrow and passable only in the dry season. This public relations gesture and a much publicized 'contribution to national development' would permit LMTC/OTC to $\log 12$ months per year, and further opens up the area to settlement and 
hunting, while the other national development benefits it brings are unclear because the area is sparsely populated and has never had important industries. No evidence exists that the standard environmental impact assessment was carried out when this activity was designed.

Given its desperate economic conditions, Liberia needs options and solutions, such as technical and financial support to the government to oversee timber concessions properly and to carry out environmental impact assessments, debt-for-nature swaps, investment by conscientious international firms, support for a national protected areas system, and much more. If these do not come soon, the vast forests of Liberia may soon be just a memory.

A copy of the 1999 Survey of the Cestos and Senkwehn Riversheds is available from the Africa Desk Officer, Fauna \& Flora International, Great Eastern House, Tenison Road, Cambridge CB1 2DT, UK. Tel.: + 441223 571 000; E-mail: info@fauna-flora.org

\section{Road rumour encourages forest clearance in Kerinci Seblat National Park}

The connection between road building and habitat destruction is being proven again in the Kerinci Seblat National Park, Sumatra, Indonesia. NGOs working in the park, currently the subject of a SUS 30-million World Bank Integrated Conservation and Development Programme, report that more than 400 families have cleared approximately 1000 ha of national park forest in the last 2 months in the wake of rumours of a new road being built through the national park.

Clearances started even before the newly installed Bupatti (District Office) of Kerinci had written formally to national park officials requesting their views on a new road running through national park forests to link the heavily populated Kerinci enclave with Muara Bungo to the east. The new road was proposed by the Bupatti to replace the existing Kerinci-Bangko road, which has been badly damaged by landslides caused by illegal clearance of protected forests

National park officials are believed to have strongly opposed the proposed new road, which would give access to the last surviving virgin forests in the Kerinci area. However, under the Indonesian government's new policy of devolving power to the regions, the national park and Department of Forestry's powers of veto may soon be weakened.

Source: Fauna \& Flora International, 1 November 1999.

\section{Illegal logging in Indonesia threatens the future of the country's forests}

Illegal logging is threatening Indonesian forests and the threatened species they contain. For example, a recent survey funded by the Indonesia-UK Tropical Forest Management Programme and carried out in conjunction with park employees and the local office of the World Wide Fund for Nature (WWF) discovered 25 unlicensed sawmills in the immediate vicinity of the Bukit Tigapuluh National Park, which straddles the border between the provinces of Jambi and Riau on the island of Sumatra. These sawmills have no official supply of raw materials and thus rely upon an illegal supply of timber from the surrounding forests. Gangs of illegal loggers, some local and some from further afield, commonly use the infrastructure developed by concessionaires to gain access to the forest and then transport illegally felled timber to their markets. Illegally felled logs are sold on to the mills at a price well below their market value.

The park covers roughly 127,000 ha, of which about 57,000 ha are ex-limited, production forest and 70,000 ha are protection forest. The area is rich in biodiversity, with 700 recorded plant species, 246 of which are used by indigenous communities in and around the park. There are also 192 species of bird as well as 59 species of mammals, including the highly endangered Sumatran tiger Panthera tigris, Sumatran elephant Elephas maximus, clouded leopard Neofelis nebulosa, oriental small-clawed otter Aonyx cinerea and Malayan tapir Tapirus indicus.

By logging in areas already disturbed by concessionaires, illegal loggers take future crop trees and damage the residual stand, often to a point where no future harvest will be possible. Once an area of forest has been thus damaged, it is easy for concessionaires to apply to the government for a permit to clear-fell the land, profit from the sale of the remaining timber, then plant oil palm.

Tackling illegal logging in this area, and indeed throughout Indonesia, is going to be very difficult as a result of the involvement of uniformed officials. A typical arrangement for a sawmill in the area appears to be that it is set up with capital from the local Chinese or indigenous business communities with the backing of either government employees or members of the military. The llegal loggers themselves are often residents of forest-fringe communities who lost access rights to the forest, when industrial harvesting licences were granted to Jakarta-based logging companies in the 1970s and 1980s. These disenfranchized communities feel cheated and thus continue to plunder the forest for timber. With the backing of the military and the government, mill owners and operators can run their businesses with impunity and cannot be brought to account for their actions in court or through other official channels. Unless 
this culture of corruption is changed, illegal logging will continue until only a worthless rump of the existing forest estate remains in Indonesia.

The problem of illegal logging arises from a large discrepancy between the supply and apparent demand for roundwood in Indonesia. The official licensed log supply in 1998 was 29.5 million $\mathrm{cu} \mathrm{m}$ of roundwood. Export data and estimated domestic requirements suggest that over 62 million $\mathrm{cu}$ m of Indonesian roundwood were consumed in the same year (after accounting for imports), revealing an unrecorded and largely illegal harvest of over 32 million $\mathrm{cu} \mathrm{m}$ of roundwood per annum. This intensity of forest exploitation is highly unsustainable.

Despite severe damage being caused, Indonesia's forest rangers are powerless to stop the problem. Only 13,000 rangers, with poor logistical support, are employed to police an area of forest covering at least 100 million ha-one ranger for every 7600 ha of forest. Despite recently instigating a series of wide-sweeping reforms in the forestry sector, the Indonesian government has yet to take any meaningful steps towards tackling the problem of illegal logging. Although the recent forest sector reforms are well intended, they will ultimately prove meaningless unless illegal logging can be curbed and current rates of harvesting brought down to a sustainable level. Unless action is taken immediately, the problem will continue insidiously until no forests of any commercial or biological value remain.

Illegal logging is essentially driven by supply and demand. The export orientated wood-processing industry has been allowed to expand without any reference to the sustainable supply of timber, while domestic demand (in a country of more than 200 million people) has been neglected by government planners altogether. The imbalance between supply and demand arose because woodprocessing mills are licensed by the Ministry of Industry and Trade, while forest exploitation is licensed by the Ministry of Forestry and Estate Crops. There has been little or no co-ordination between these two departments over exploitation of the country's forests, resulting in the vast over-capacity seen in the industry today.

If illegal logging is to be stopped, a determined stance to eradicate the problem must first be taken in the top echelons of the Indonesian government and the higher ranks of the military. Without strong political backing, all initiatives will be doomed to failure. The government must then strive to eliminate grassroots corruption, which undermines all attempts to improve management of the country's forests. Steps must be taken to reduce the imbalance between supply and demand. There are many options that could be used by the government to bring about this end. Any workable solution to the demand-side of the equation is likely to involve all stakeholders, including those currently branded illegal loggers, while a resolution to supply-side problems must involve a ban on all further clear-cutting, expanded plantation development on degraded land, and more efficient use of the timber resource. It would also be prudent to increase the resources and personnel detailed to police forests in Indonesia.

Source: Indonesia-UK Tropical Forest Management Programme (ITFMP), Report number: PFM/EC/99/03.

The ITFMP is a programme of technical co-operation activities funded jointly by the Indonesian Ministry of Forestry and Estate Crops and the UK Department for International Development (DFID). The overall purpose of the programme is to improve the capacity of government, industry and local communities to implement responsive and responsible management policies and practices in Indonesia's natural forests.

ITFMP, Gedung Manggala Wanabakti, Blok. VII, Lt. 6, II. Jend. Gatot Subroto, Jakarta 10270, Indonesia Tel./Fax: + $620215720225 ;$ E-mail:itfmp@cbn.net.id

\section{Sumatran park cracks down on animal trade}

One of Indonesia's largest national parks plans to step up enforcement of the country's tough but rarely applied laws on the trade and ownership of protected animal and bird species. Managers of the 13,500-sq-km Kerinci-Seblat National Park in central Sumatra announced in August that park rangers and staff will target illegal ownership of and trade in species protected under Indonesian and international law.

The Kerinci-Seblat National Park and its surrounding forests are believed to be a major source of many of the protected species openly owned and traded both in Sumatra and at Jakarta's Pasar Pramuka animal market. Among protected species known to be captured illegally from the national park and surrounding forest for the exotic animal and bird trade are sunbear cubs Helarctos malayanus, siamang Hylobates syndactylus and agile gibbons $H$. agilis, slow loris Nycticebus coucang, leopard cats Felis bengalensis, birds of prey and hornbills, as well as songbirds and endemic pheasants.

The new policy comes as a \$US 25-million World Bank Integrated Development and Conservation Programme, intended to produce a viable future for both the park and forest-edge communities, moves into top gear. It includes increased funding for conservation and enforcement, and for a range of new anti-poaching initiatives across the national park. More funds are coming to the park via Fauna \& Flora International (FFI), to provide additional specialist anti-poaching units to protect the park's 
Sumatran tigers Panthera tigris and other critically endangered species.

Among the first results of the new 'immediate confiscation' policy were the seizure and release, in late August, of a rhinoceros hornbill Buceros rhinoceros, which was found by a park ranger patrol just after it had been shot with an airgun by a poacher in a park-edge village in West Sumatra. Rangers rescued the bird and took it to park headquarters for veterinary treatment before release, a week later.

Park authorities and FFI are urgently seeking funding for a simple holding centre and sanctuary in which animals and birds confiscated under the new policy can be temporarily placed prior to release. Lack of facilities to which confiscated animals can be sent for quarantine and later release are a major reason for non-enforcement of Indonesia's comprehensive laws on wildlife protection.

Source: Fauna \& Flora International.

\section{'Fossil' lizard found alive in the Canary Islands}

A giant lizard, supposedly extinct and belonging to the genus Gallotia (Lacertidae) was discovered in June 1999 on La Gomera Island in the Canarian Archipelago (Plate 1). This genus is endemic to the Canary Islands and is a remarkable example of adaptive radiation (Arnold, 1989; González et al., 1996; Rando et al., 1997).

Several studies on fossil bones suggested that two species of these giant lizards Gallotia goliath (about $1.5 \mathrm{~m}$. long) and $G$. simonyi $(50-70 \mathrm{~cm}$ long) inhabited the western islands (Tenerife, La Gomera, La Palma and El Hierro) of the archipelago (see review in Bischoff, 1998). However, some authors believe that the two lizards should be considered as the same species ( $G$. simonyi), which suffered a reduction in body size after the arrival of humans in the islands about 2500 years ago (Mateo et al., 1999; Barahona et al., in press).

Until recent years the only known living giant lizard on these islands was $G$. simonyi from Roque Chico de Salmor off El Hierro. It disappeared from this rock about 65 years ago but a small population was found in 1974 on some cliffs (Fuga de Gorreta) on El Hierro itself (Machado, 1985). In May 1996 a new species, G. intermedia, was discovered in coastal cliffs on Tenerife (Hernandez et al., in press).

That discovery led to the possibility that another species of giant lizard might still survive in remote parts of the island of La Gomera. Living giant lizards on this island, presumably of this group, were seen by Fritsch (1870) in the second half of the nineteenth century. Furthermore, Hutterer (1985) described two Gomeran

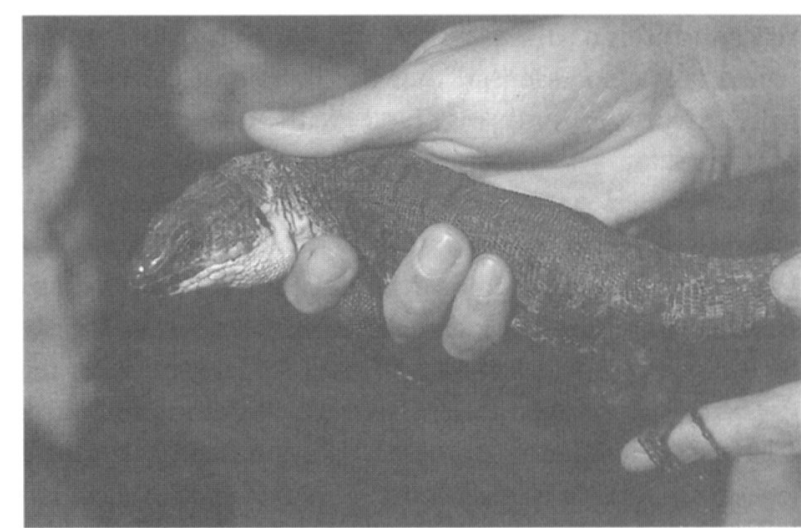

Plate 1 The new species of giant 'fossil' lizard, Gallotia sp., found on La Gomera, Canary Islands (A. Martín).

subspecies Gallotia goliath bravoana (snout-vent length estimated about $38 \mathrm{~cm}$ ) and $G$. simonyi gomerana $(21 \mathrm{~cm})$ based on subfossil bones. Some bones of the latter subspecies were found in an archaeological site dated about BP 500 and Hutterer suggested that it might still survive in some inaccessible place of La Gomera.

In June 1999 a scientific team from the University of La Laguna started a systematic search of coastal areas of La Gomera (to $400 \mathrm{~m}$ a.s.l.). After searching many places, a large, recent, lizard faecal pellet was found and intensive trapping during 4 months (5 June-2 October) eventually resulted in the capture of one juvenile (probably female) and five adults (two males: 18.0 and $19.0 \mathrm{~cm}$, snout-vent length; and three females: 13.5, 15.0 and $15.5 \mathrm{~cm}$ ). The largest individual was $49.0 \mathrm{~cm}$ from nose to end of tail.

The new lizard is different from any other known species on the archipelago. The dorsal and lateral coloration is dark with small blue spots on the flanks, and the ventral parts (including the distinctive gular region, limbs and tail) are ivory white. Body size corresponds with the form described by Hutterer (1985) as G. simonyi gomerana from bone remains. Taking into account the morphological characters, this lizard belongs to the 'simonyi group' and may be a new species. Geneticists from the University of Laguna are carrying out DNA studies to compare them with other Gallotia species. Most of the main areas of La Gomera Island that might be suitable habitat have now been surveyed with no further success and it seems that this lizard could be one of the most endangered reptiles in the world. Introduced cats and rats are present in the small area where this lizard has been found and in a short period of time preliminary trapping yielded eight feral cats in this zone, so conservation measures require not only eradication or control of these predators but also an urgent captive breeding plan. The lizards must be raised in situ (Valle Gran Rey) to guarantee similar climatic conditions and to minimize 
risk of foreign diseases. To ensure a future for this lizard it is also essential that the people of Gomera are fully aware of and involved with the conservation measures.

\section{Acknowledgments}

We thank Juan J. Ramos Manuel Siverio, Efraín Hernández, Juan C. Illera, Juan M. Martínez, José Dámaso, Jacinto Leralta and Ruben Martínez for assistance in the fieldwork. We thank the Canarian government (Viceconsejería de Medio Ambiente) for financing this project. The Unidad de Medio Ambiente del Cabildo Insular de La Gomera gave all kinds of logistic support and together with the Unidad de Helicópteros $n^{\circ} 11$ de la Guardia Civil en S/C de Tenerife ( $151^{\text {a }}$ Comandancia) provided us with their helicopter to reach otherwise inaccessible places. We are also grateful to many people from La Gomera who advised us on safe access to dangerous sites, particularly Manuel Gutiérrez and Juan Plasencia. This fascinating discovery is dedicated to the people of La Gomera.

\section{References}

Arnold, E.N. (1989) Towards a phylogeny and biogeography of the Lacertidae: relationships within an Old-World family of lizards derived from morphology. Bulletin British Museum Natural History, London, 55, 209-257.

Barahona, F., Evans, S.E., Mateo, J.A., García-Márquez, M. \& López-Jurado, L.F. (in press) Endemism, gigantism and extinction in island lizards: the genus Gallotia on the Canary Islands. Journal of Zoology.

Bischoff, W. (1998) Bemerkungen zu den 'fossilen' Rieseneidechsen der Kanarischen Inseln. In Handbuch der Reptilien und Amphibien Europas. 6. Die Reptilien der Kanarischen Inseln, der Selvagens-Inseln und des Madeira Archipels (ed. W. Bischoff), pp. 387-407. Aula-Verlag Wiesbaden, Bonn.

Fritsch, K. v. (1870) Ueber die ostatlantischen Inselgruppen. Berichte der Senckenbergischen naturforschenden Gesellschaft, 1870, 72-113.

González, P., Pinto, F., Nogales, M., Jiménez-Asensio, J.J., Hernández, M. \& Cabrera, V.M. (1996) Phylogenetic relationships of the Canary Islands endemic lizard genus Gallotia (Sauria: Lacertidae), inferred from mitochondrial DNA sequences. Molecular Phylogenetics and Evolution, 6, $63-71$.

Hernández, E., Nogales, M. \& Martín, A. (in press) Discovery of a new lizard in the Canary Islands, with a multivariate analysis of Gallotia (Reptilia: Lacertidae). Herpetologica.

Hutterer, R. (1985) Neue Funde von Rieseneidechsen (Lacertidae) auf der Insel Gomera. Bonner zoologische Beitrage, 36, 365-394.
Machado, A. (1985) New data concerning the Hierro Giant lizard and the Lizard of Salmor (Canary Islands). Bonner zoologische Beitrage, 36, 429-470.

Mateo, J.A., López-Jurado, L.F. \& García-Márquez, M. (1999) Cuántas especies del género Gallotia había en la isla de El Hierro? Monografias de Herpetologia, 4, 7-16.

Rando, J.C., Hernández, E., López, M. \& González, M. (1997) Phylogenetic relationships of the Canary Islands endemic lizard genus Gallotia inferred from mitochondrial DNA sequences: incorporation of a new subspecies. Molecular Phylogenetics and Evolution, 8, 114-116.

Alfredo Valido, Juan Carlos Rando, Manuel Nogales and Aurelio Martín. Departamento de Biología Animal (Zoología), Universidad de La Laguna 38206, La Laguna, Tenerife, Canary Islands, Spain. E-mail: mnogales@ull.es

\section{Ambitious biodiversity inventory in Great Smoky Mountains}

The All Taxa Biodiversity Inventory (ATBI) is an ambitious project, which is at present in a 2-year pilot phase in the USA. Led by the National Park Service and a non-profit organization, Discover Life in America, the project is inviting scientists to tally every species that occurs in the 2250-sq-km Great Smoky Mountains National Park, which straddles the border of Tennessee and North Carolina. So far scientists have identified only 9800 of an estimated 100,000 species (excluding bacteria and viruses) but have found at least five new species of Diptera, which were collected in just one weekend.

The original concept was conceived 6 years ago by Daniel Janzen of the University of Pennsylvania, who wanted to carry out an ATBI in an area of forest in Guanacaste, Costa Rica. However, it was estimated to cost \$US 90 million so Costa Rica officials opted for a limited survey instead.

The ATBI idea was revived in the USA with the Great Smoky Mountains National Park being selected because it is one of the most species-rich temperate areas in the world. Park officials have pledged to build a laboratory, which will be open to ATBI researchers, at a cost of \$US 3 million in 2001. Scientists are still working out the best methods to use, but 201 -ha plots have already been delineated for sampling purposes. The project has a web site that logs all the species found and eventually this will include data on each species's range, behaviour and population dynamics (www.discoverlife.org).

Source: Science (1999), 284, 1747-1748. 